\title{
Distribution and characterization of plasmalemma vesicle protein-1 in rat endocrine glands
}

\author{
R Hnasko, M McFarland and N Ben-Jonathan \\ Department of Cell Biology, Neurobiology and Anatomy, University of Cincinnati Medical School, 3125 Eden Ave, Cincinnati, Ohio 45267, USA \\ (Requests for offprints should be addressed to N Ben-Jonathan; Email: Nira.Ben-Jonathan@uc.edu)
}

\begin{abstract}
Plasmalemma vesicle protein-1 (PV-1) is an integral membrane protein associated with endothelial cell caveolae and fenestrae. Since endocrine glands are enriched with fenestrated endothelium, we examined the distribution of PV-1 mRNA and protein in endocrine glands and determined its cellular localization. A single transcript was detected by RT-PCR in all endocrine glands examined. A synthetic peptide was used to generate antibodies for Western blotting and immunohistochemistry (IHC). Western blotting of membrane fractions from lung, pituitary, adrenal, testis and PV-1-transfected Cos-1 cells revealed a major $65 \mathrm{kDa}$ protein. This protein binds to heparin with high affinity. Using IHC, PV-1 was localized to both endothelial cells of the adrenal zona reticularis and chromaffin cells of the medulla. In the pancreas, PV-1 expression was restricted to a few cells in the islets of Langerhans that partially overlap with somatostatin-positive $\delta$-cells. In both neonatal and adult pituitaries, strong PV-1 immunoreactivity was detected in neural lobe pituicytes in a
\end{abstract}

pattern similar to that of glial fibrillary acidic protein (GFAP). PV-1 and GFAP expression was seen in the adult, but not neonatal, intermediate lobe. Endothelial cells throughout the neonatal anterior lobe were PV-1 positive, but PV-1 in the adult was restricted to some endothelial and endocrine cells localized near the margins of lobe. In the adult testis, strong PV-1 expression was seen in germ cells within the seminiferous tubules that varied with the stage of spermatogenesis. In contrast, PV-1 in the neonatal testis was localized to the interstitial cells but not seminiferous tubules. In the ovary, PV-1 was expressed in stromal endothelial cells as well as the thecal layer of developing follicles. Over half the corpus luteal cells were positive for PV-1. Our data have shown that PV-1 is not restricted to endothelial cells but is localized in many types of endocrine and non-endocrine cells. Furthermore, PV-1 expression in the pituitary and testis is developmentally regulated.

Journal of Endocrinology (2002) 175, 649-661

\section{Introduction}

Plasmalemma vesicle protein-1 (PV-1) is a 438 amino acid membrane protein isolated from the rat lung (Stan et al. 1999a). The rat, mouse and human PV-1 genes have been cloned and encode highly conserved transcripts of six exons (Stan et al. 2001). In the rat, a single PV-1 transcript of 1968 nucleotides was detected by Northern blot in the lung, kidney and liver with a much weaker expression in other tissues and undetectable levels in the testis (Stan et al. 1999a, 2001). Structural analysis predicts a protein with a single hydrophobic transmembrane region separating a short (27 amino acid) cytoplasmic N-terminal domain and a large (380 amino acid) extracellular C-terminal domain (see Fig. 1B). The extracellular region is $\mathrm{N}$-glycosylated, contains nine conserved cysteine residues and is prolinerich at the C terminus (Stan et al. 1999a, 2001). There is little sequence similarity of PV-1 with known genes or proteins in the current databases.

The highest level of PV-1 protein in rat tissues was detected by Western blotting in lung membranes as a single band of approximately $60 \mathrm{kDa}$ under reducing conditions or as a band of $110 \mathrm{kDa}$ under non-reducing conditions, suggesting dimer formation. Weak bands were evident in membrane fractions from kidney, spleen, liver, adrenal, pancreas and intestinal mucosa, but PV-1 was undetectable in heart, muscle, brain or testis (Stan et al. 1999a,b). PV-1 was undetectable in rat lung cytosol fractions or plasma. In frozen sections, PV-1 was localized by immunofluorescence to capillaries within the adrenal cortex, pancreas, intestine and kidney peritubules, but not the heart (Stan et al. 1999b). Using immuno-gold electron microscopy, PV-1 was seen associated with the nonmembranous diaphragms (Bearer \& Orci 1985) of endothelial cell fenestrae, caveolae and transendothelial channels (Stan et al. 1999b). Fenestrae are circular openings that perforate the attenuated portion of the endothelial cell and are involved in solute exchange (Milici et al. 1985, Clough 1991, Irie \& Tavassoli 1991) whereas caveolae are plasma membrane invaginations that participate in both transport and signaling (Milici et al. 1986, Gumbleton et al. 2000, Couet et al. 2001, Matveev et al. 2001). Hence, 


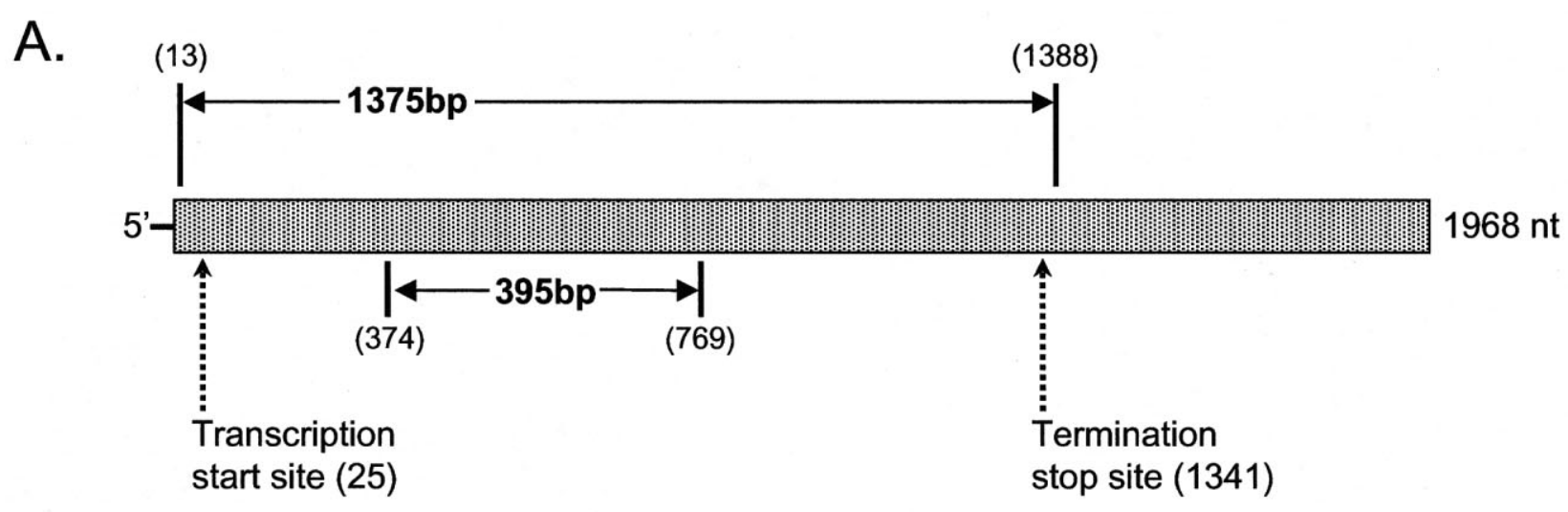

B.

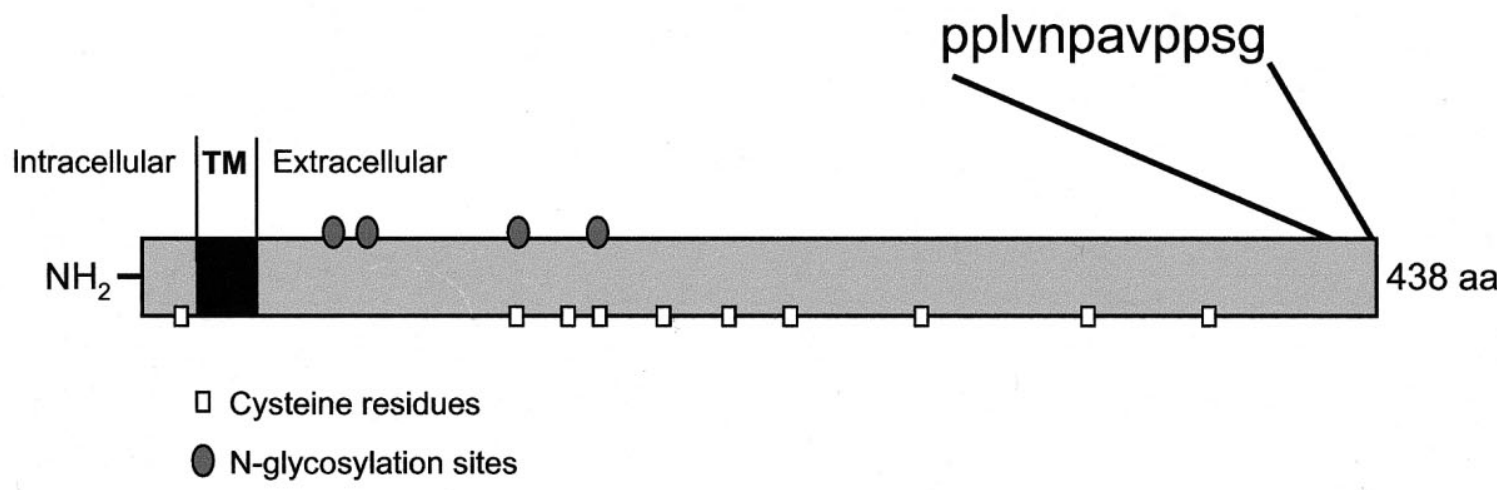

Figure 1 Diagram of the rat PV-1 mRNA transcript and protein. (A) The location of PCR primers (PV- $1_{1375}$ and PV- $1_{395}$ ) and their expected product sizes. (B) The putative structure of the PV-1 protein and the location of the $\mathrm{N}$-glycosylation sites and cysteine residues. The amino acids (aa) (PV-1C peptide) used to generate the PV-1 antibody are shown at the C terminus. TM=transmembrane domain.

PV-1 appears to represent the first biochemical marker that is shared between these organelles.

Endocrine glands are enriched with fenestrated endothelium (Simionescu et al. 1983), whereas (Bankston \& Milici 1983) fenestrae are uncommon in other tissues suggesting a specialized function (Gross et al. 1987, Takakura et al. 1998). Their role in endocrine glands could be in facilitating bidirectional hormonal exchange between endocrine cells and the blood. The notion that fenestrae are dynamic structures subject to regulatory signals is based on reports that molecules such as vascular endothelial growth factor can induce rapid fenestrae formation in some vascular beds (Lombardi et al. 1986, Roberts \& Palade 1995, Esser et al. 1998, LeCouter et al. 2001). Thus far, understanding the role of fenestrae has been limited by the lack of specific biochemical markers. Our overall objective was to examine the distribution of PV-1 within endocrine glands in order to explore its utility as a marker of endothelial cells and their fenestrae. The specific aims were to examine the expression of PV-1 mRNA and protein in select endocrine glands and deter- mine its cellular localization. Unexpectedly, our data show that PV-1 is not restricted to endothelial cells but is expressed in many types of endocrine and non-endocrine cells. Furthermore, the cellular localization of PV-1 is developmentally regulated.

\section{Materials and Methods}

\section{Animals}

Adult male and virgin female Sprague-Dawley rats (250 g) were obtained from Harlan (Indianapolis, IN, USA) and maintained under a 12-h light cycle with food and water provided ad libitum. Neonatal rats (6-7 days old) were obtained from a single litter of a pregnant female.

\section{$R T-P C R$}

Total RNA was isolated from rat tissues using TriReagent (Gibco-BRL, Rockville, MD, USA) and $5 \mu \mathrm{g}$ 
were reverse transcribed using Superscript II with random hexamers. PCR was performed on $0.75 \mu \mathrm{g}$ of the RT reaction with the following sets of primers: (1) PV-1 395 , sense primer $5^{\prime}$-AGTGCCAAGGCGACCTGAT- $3^{\prime}$ and antisense 5'-GGAACGGTAGACCAGCGAATC-3'; expected product size $=395 \mathrm{bp}$ (Fig. 1A); (2) PV-1 1375 , sense primer $5^{\prime}$-GACACTGCGCAAATGGGGCTC-3' and antisense $5^{\prime}$-ACGGGTGGGCGATTCTGGTG-3'; expected product size $=1375 \mathrm{bp}$ (Fig. 1A); and (3) glyceraldehyde-3-phosphate dehydrogenase (GAPDH), sense primer 5'-GGTGATGCTGGTGCTGAG-3' and antisense $5^{\prime}$-TCATACTTGGCAGGTTTCTCC-3'; expected product size $=506 \mathrm{bp}$. PCR conditions for PV-1 395 and GAPDH were $95{ }^{\circ} \mathrm{C}$ for $45 \mathrm{~s}, 58^{\circ} \mathrm{C}$ for $45 \mathrm{~s}$ and $72{ }^{\circ} \mathrm{C}$ for $55 \mathrm{~s}$ for 32 cycles using Taq DNA polymerase. PCR products were resolved on a $1.5 \%$ agarose gel with ethidium bromide and photographed. PCR conditions for PV $-1_{1375}$ were $95^{\circ} \mathrm{C}$ for $60 \mathrm{~s}, 58^{\circ} \mathrm{C}$ for $60 \mathrm{~s}$ and $72{ }^{\circ} \mathrm{C}$ for 90 s for 32 cycles using Pfu DNA polymerase (Promega, Madison, WI, USA) with the products resolved on a $1 \%$ agarose gel. Primer concentrations were 25 pmol and all PCR reactions included $2 \mathrm{mM} \mathrm{MgCl}$ and $8 \%$ dimethyl sulfoxide (DMSO). All experiments were carried out at least three times using RNA from different animals.

\section{$P V-1$ plasmid construction and cell transfection}

Total RNA isolated from rat pituitary was reverse transcribed and PV-1 1375 primers were used to amplify a full-length PV-1 cDNA (NCBI accession no. AF154831) using Pfu DNA polymerase as described above. The PCR product was cloned into the pcDNA3.1 vector (Invitrogen, San Diego, CA, USA) after the addition of EcoRI/NotI adaptors and sequenced. Cos-1 cells (ATCC) were transfected with $1 \mu \mathrm{g}$ pcDNA-3-PV-1 using FuGENE6 (Roche, NJ, USA), cultured for 3 days and harvested for Western blotting or heparin affinity chromatography.

\section{PV-1 antibody production}

A synthetic 15-mer peptide (CKGPPLVNPAVPPSG= PV-1C; see Fig. 1B) corresponding to the last 12 amino acids of rat PV-1 C terminus (CKG was added to facilitate coupling and solubility; Stan et al. (1999a)) was coupled to keyhole limpet hemocyanin for immunization of hens (Bethyl, Montgomery, TX, USA). Chicken IgY was isolated from eggs and affinity purified using an agarosePV-1C peptide column. Affinity-purified chicken antirat-PV-1 $(1 \cdot 67 \mu \mathrm{g} / \mu \mathrm{l})$ or non-immune chicken IgYs (Aves Labs, Tigard, OR, USA) at the same concentration were used for Western blotting and immunohistochemistry.

\section{Western blotting}

Tissues were homogenized on ice in $25 \mathrm{mM}$ HEPES buffer ( $\mathrm{pH} 7 \cdot 2$ ) with $250 \mathrm{mM}$ sucrose, $2 \mathrm{mM} \mathrm{MgCl}_{2}$,
$1 \mathrm{mM}$ phenylmethylsulfonyl fluoride and a cocktail of protease inhibitors (Sigma, St Louis, MO, USA). Tissue homogenates were passed through a $70 \mu \mathrm{m}$ nylon mesh and centrifuged at $500 \mathrm{~g}$ for $30 \mathrm{~min}$ at $4{ }^{\circ} \mathrm{C}$. Supernatants were then centrifuged at $100000 \boldsymbol{g}$ for $90 \mathrm{~min}$ and divided into membrane or cytosolic fractions. Membranes were solubilized in $50 \mathrm{mM}$ Tris- $\mathrm{HCl}(\mathrm{pH} 6 \cdot 8)$ with $0.5 \%$ SDS and protein concentration was determined. Lung $(20 \mu \mathrm{g})$ or membrane proteins from endocrine glands $(150 \mu \mathrm{g})$ were added to an equal volume of $2 \times$ sample buffer containing $10 \% \beta$-mercaptoethanol, boiled for $10 \mathrm{~min}$ and separated by electrophoresis on a $4-20 \%$ gradient polyacrylamide gel. Proteins were transferred to nitrocellulose membranes (Gibco-BRL), blocked with 5\% non-fat dry milk, and incubated with anti-PV-1 (1:5000), followed by a peroxidase-labeled rabbit anti-chicken IgG (1:30 000; Sigma). Immunoreactive bands were visualized on X-ray film using SuperSignal (Pierce, Rockford, IL, USA)enhanced chemiluminescence reagents. Pituitary extraction was done as described above with or without a detergent $(0 \cdot 1 \%$ Triton X-100 or Nonidet P-40). Protein loads were $20 \mu \mathrm{g}$ for lung membranes and $200 \mu \mathrm{g}$ for either membrane or cytosolic pituitary extracts.

\section{Heparin affinity chromatography}

Cos-1 cells transfected with PV-1 plasmid were sonicated in HEPES buffer on ice. Membrane proteins $(250 \mu \mathrm{g})$ were passed three times over a $1 \mathrm{ml}$ HiTrap heparin affinity column (Amersham-Pharmacia, Uppsala, Sweden) at a flow rate of $200 \mu \mathrm{l} / \mathrm{min}$ using fast protein liquid chromatography (ÄKTA explorer; AmershamPharmacia). Fractions $(200 \mu \mathrm{l})$ were eluted using a linear $\mathrm{NaCl}$ gradient $(0 \cdot 05-2 \mathrm{M}$ in $10 \mathrm{mM}$ phosphate buffer (PB) $\mathrm{pH} 7 \cdot 6$ ). Western blotting was performed as described above on $10 \%$ of the collected fractions or $20 \mu \mathrm{g}$ total membrane proteins. Membrane or cytosolic fractions from rat lung were fractionated on a heparin column using a discontinuous $\mathrm{NaCl}$ gradient. The protein load for lung membrane and cytosolic fractions was $1 \mathrm{mg}$ and $2 \mathrm{mg}$ respectively. Fractions $(2 \mathrm{ml})$ were dialyzed against HEPES buffer overnight at $4{ }^{\circ} \mathrm{C}$ and concentrated. Protein load on the gel was $20 \mu \mathrm{g}$ unfractionated lung membrane proteins, $50 \mu \mathrm{g}$ fractionated membrane proteins or $150 \mu \mathrm{g}$ fractionated cytosolic proteins.

\section{Immunohistochemistry}

Tissues were fixed in $4 \%$ paraformaldehyde with $2.5 \%$ glutaraldehyde for $6 \mathrm{~h}$ at $4{ }^{\circ} \mathrm{C}$, dehydrated, embedded in paraffin and sectioned at $5 \mu \mathrm{m}$. Slides were deparaffinized in xylene, dehydrated in graded ethanol and hydrated in $50 \mathrm{mM} \mathrm{PB}(\mathrm{pH} 7 \cdot 5)$. Endogenous peroxidase activity was inhibited with $3 \% \mathrm{H}_{2} \mathrm{O}_{2}$ in $\mathrm{PB}$ for 30 min followed by $15 \mathrm{~min}$ of high power microwaves in an antigen retrieval solution (H-3300; Vector, Burlingame, CA, USA). After 

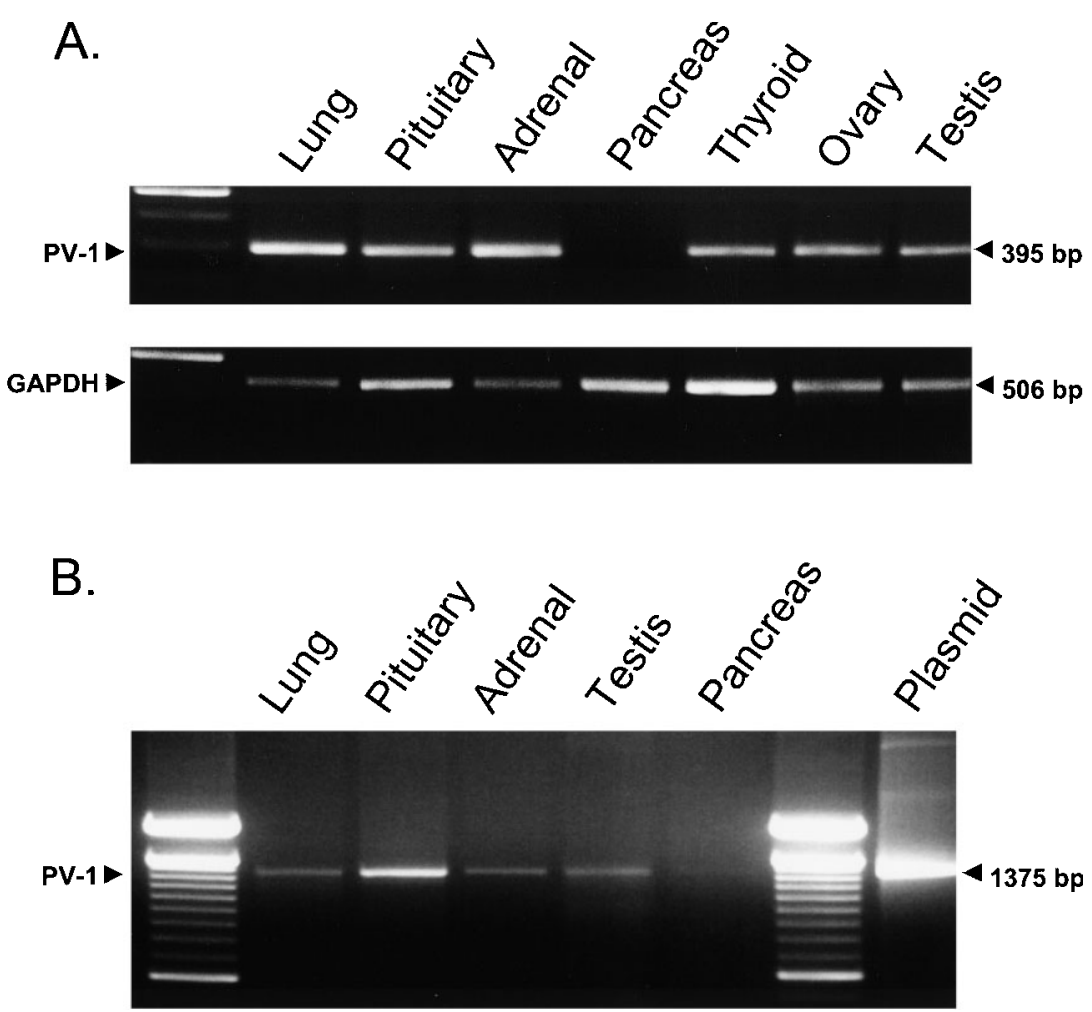

Figure 2 Expression of PV-1 mRNA in rat endocrine glands by RT-PCR. (A) The PCR products of endocrine glands that express PV-1 (395 bp) relative to an internal GAPDH control (506 bp). Rat lung is included as a positive control. (B) The expression of a single full-length PV-1 transcript (1375 bp) by PCR, using pcDNA3-PV-1 plasmid as a positive control.

cooling to room temperature, sections were blocked using HenBLKII (1:5 in PB; Aves) for $3 \mathrm{~h}$. Primary antibodies (chicken anti-rat PV-1 (1:1500) or non-immune chicken $\operatorname{IgY}(1: 1500)$, rabbit anti-somatostatin $(4 \mu \mathrm{g} / \mu \mathrm{l}$; Innogenex, San Ramon, CA, USA), rabbit anti-bovine glial fibrillary acidic protein (GFAP; $4 \mu \mathrm{g} / \mu \mathrm{l}$; Innogenex) or rabbit IgG control ( $4 \mu \mathrm{g} / \mu \mathrm{l}$; Jackson, Bar Harbor, ME, USA)) were diluted in PB with $2.5 \%$ normal goat serum and applied to sections overnight. This was followed by incubation for $3 \mathrm{~h}$ with biotinylated goat anti-chicken or anti-rabbit IgGs $(1.5 \mathrm{mg} / \mathrm{ml}$; Vector $)$ diluted $1: 2000$ in $\mathrm{PB}$. Immunoreactive products were visualized using avidin-peroxidase (PK-7100; Vector) and diaminobenzidine substrate (Vector). Sections were counterstained with Mayer's hematoxylin and digital images were taken with a spotcam (Diagnostic Instruments, Sterling Heights, MI, USA) attached to a Nikon Microphot-FXA microscope.

\section{Results}

Expression of $P V-1 m R N A$ in endocrine glands

RT-PCR was used to determine the expression of the PV-1 transcript in various endocrine glands, with the lung serving as a positive control (Fig. 2). As shown in Fig. 2A, PV $-1_{395}$ is seen in the lung, pituitary and adrenal with a weaker expression in the thyroid, ovary and testis. The pancreas showed no detectable PV-1 expression although the presence of GAPDH confirms the integrity of the sample. A full length PV-1 1375 transcript was detected in the lung, pituitary, adrenal and testis (Fig. 2B), supporting the expression of a single transcript by these glands. A very weak band was seen in the pancreas using this primer set. Purified pcDNA-3-PV-1 plasmid was included as a positive control. A single full-length $\mathrm{PV}-1$ product was detected when Cos cells were transfected with the PV-1 plasmid (data not shown).

Variable detection of $P V-1$ protein in endocrine glands

The expression of the PV-1 protein in membrane fractions of rat endocrine glands was determined by Western blotting (Fig. 3). Figure 3A shows a single band of $\cong 65 \mathrm{kDa}$ in lung, adrenal and testes under reducing conditions. PV-1 protein was undetectable in membrane fractions of pituitary, pancreas, thyroid or ovary under these conditions. Furthermore, PV-1 protein was not detected in the cytosolic fractions of any of these tissues 


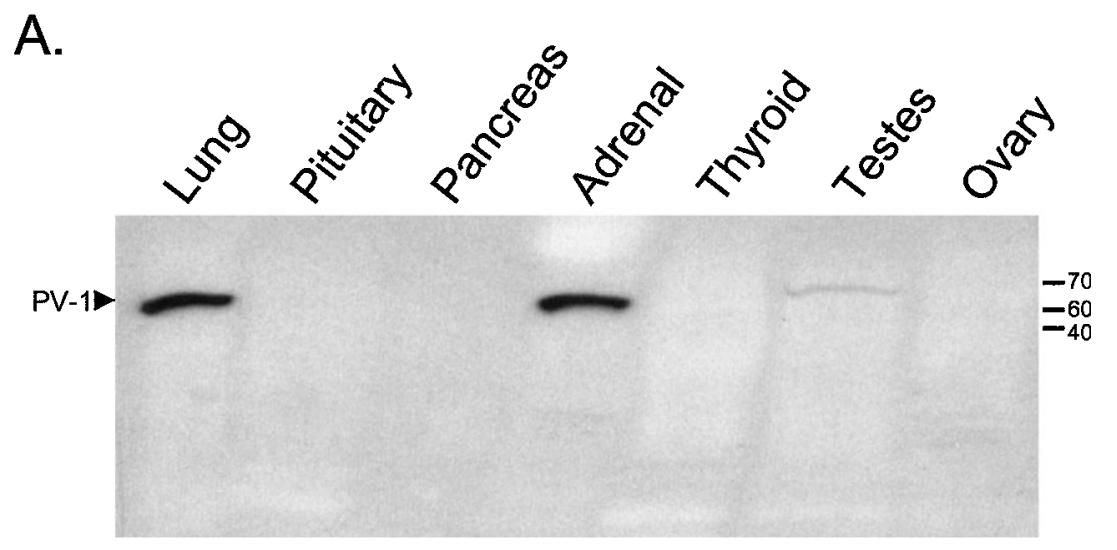

B. Pituitary gland

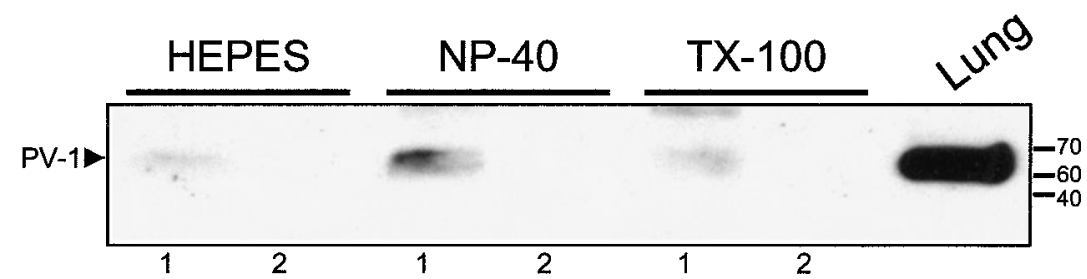

Figure 3 Detection of PV-1 protein in endocrine glands by Western blot. (A) Detection of a single $65 \mathrm{kDa}$ protein band from membrane fractions. (B) Comparison of PV-1 detection from the pituitary gland ( $1=$ membrane proteins; $2=$ cytosolic proteins) using different solubilizing agents. Lung membrane proteins are included as a positive control.

(data not shown). To determine whether solubilizing agents increase the recovery of PV-1 protein, pituitary glands were extracted in the presence of the non-ionic detergents Triton X-100 or Nonidet P-40. As shown in Fig. 3B, PV-1 protein was detected in the membrane, but not cytosolic, fractions of all pituitary extracts. The most effective extraction of PV-1 was accomplished using Nonidet P-40, whereas HEPES alone was least effective.

\section{$P V-1$ binds heparin with a strong affinity}

Membranes from PV-1-transfected Cos cells were fractionated on a heparin affinity column, using a linear gradient of $\mathrm{NaCl}$. Western blot showed that PV-1 bound to heparin with a strong affinity, eluting at $2 \cdot 0 \mathrm{M} \mathrm{NaCl}$, and was undetected in the unbound fraction (Fig. 4A). Both fractionated and unfractionated Cos- 1 cell membranes showed a predominant $65 \mathrm{kDa}$ band, whereas no band was detected in untransfected Cos cells. PV-1 protein bands were undetectable when the PV-1 antibody was preabsorbed with the PV-1C peptide (data not shown). As shown in Fig. 4B, endogenous PV-1 from lung extracts binds heparin, with the majority of the protein eluting between 1 and $2 \mathrm{M} \mathrm{NaCl}$. Interestingly, PV-1 was also detectable in the unbound fraction from the lung membranes and weak bands were seen in fractions of cytosolic proteins.

\section{$P V-1$ is localized to both adrenal chromaffin cells and endothelial cells of the zona reticularis}

Using immunohistochemistry, the cellular distribution of PV-1 in the rat adrenal gland was examined (Fig. 5). At low magnification, PV-1 protein was observed in the adrenal medulla and the zona reticularis of the cortex but not in the zona fasciculata, zona glomerulosa or capsule (Fig. 5A). At higher magnification, strong cytoplasmic staining was evident in chromaffin cells of the medulla (Fig. 5C) and in endothelial cells of the zona reticularis (Fig. 5E). No staining was seen when IgY was used as a control (Fig. 5B, D and F).

$P V-1$ is restricted to a few endocrine cells within the pancreatic islets

Figure 6 clearly shows that PV-1 expression is limited to a small number of endocrine cells within the islets of Langerhans (Fig. 6A). PV-1 was undetectable in the 
A.

\section{Heparin fractions}

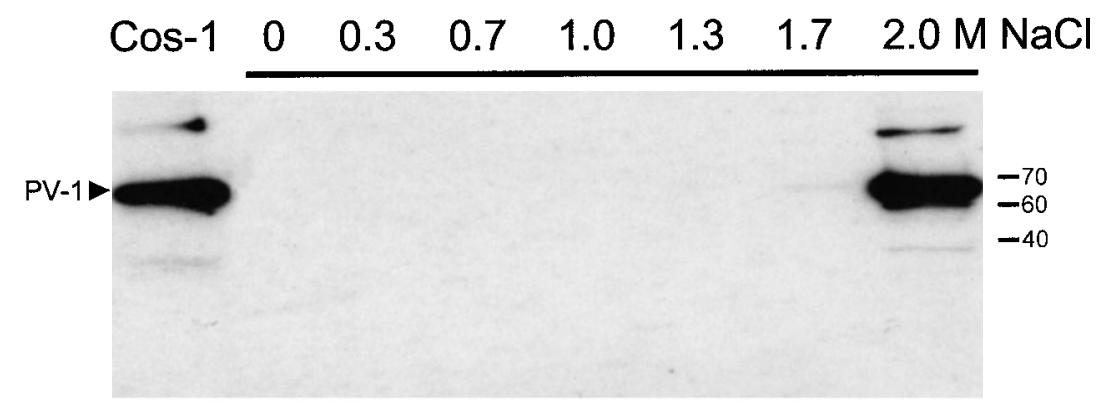

B. Heparin fractions Membranes Cytosol

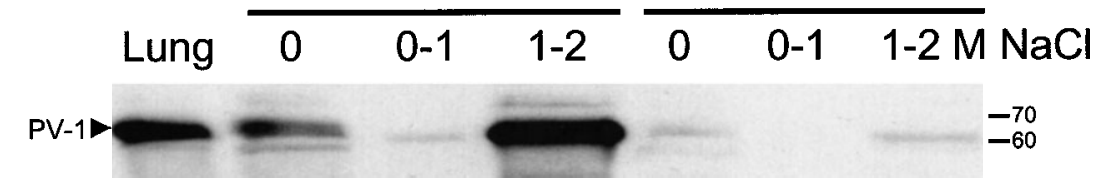

Figure 4 PV-1 protein binds to a heparin affinity column. (A) Detection of PV-1 by Western blot from membrane proteins of PV-1 transfected-Cos-1 cells fractionated on a heparin column using a linear $\mathrm{NaCl}$ gradient. (B) Detection of PV-1 by Western blot from rat lung membrane or cytosolic proteins following elution from heparin with a discontinuous $\mathrm{NaCl}$ gradient.

exocrine pancreas with the exception of a few PV-1positive cells that line large interlobular ducts (data not shown). The limited distribution of PV-1-positive cells within the islets suggests that their expression is not prominent in the more abundant glucagon-producing $\alpha$-cells or insulin-secreting $\beta$-cells. To examine whether PV-1 is localized to the somatostatin-producing $\delta$-cells (Goldsmith et al. 1975), serial sections were immunostained for somatostatin and PV-1. As evident in Fig. 6C and $\mathrm{E}$, immunostaining for PV-1 shows partial overlap with somatostatin-positive cells (Fig. 6D).

$P V-1$ is expressed by several cell types within the neonatal and adult pituitary gland

The cellular distribution of immunoreactive PV-1 in neonatal (1 week old) and adult pituitary glands was compared (Fig. 7). The anterior (AL), intermediate (IL) and neural (NL) lobes of the pituitary are outlined in the hematoxylin-stained IgY controls (Fig. 7A and B). Abundant PV-1 staining was seen in the NL of both neonatal and adult pituitaries (Fig. 7C and D), whereas the adult IL showed a stronger PV-1 staining than that of the neonate. Interestingly, PV-1 was evident in some cell nuclei within the neonatal NL (Fig. 7I). The expression of GFAP, an established marker for pituicytes (Salm et al. 1982), resembled that of PV-1 in both neonatal and adult NL (Fig. 7E and F). In the adult IL, composed primarily of melanotrophs (Lugo \& Pintar 1996), the pattern of GFAP staining was similar to that of PV-1 whereas little GFAP reactivity was seen in the neonatal IL. Endothelial cells throughout the neonatal AL and those in the periphery of the adult AL were positive for PV-1 (Fig. 7G and H), but appear not to express PV-1 in the NL (Fig. 7I and J). Some endocrine cells within the adult, but not neonatal AL, were also positive for PV-1 (Fig. $7 \mathrm{H}$ ).

\section{Differential cellular localization of $P V-1$ in the neonatal and adult testis}

PV-1 distribution in the immature testis of the neonate was compared with the fully differentiated testis of the adult (Fig. 8). In the neonatal testis, PV-1 was primarily localized to the interstitium with sporadic positive cells seen within the seminiferous tubules (Fig. 8A). Strong PV-1 immunostaining was seen in some interstitial cells that may represent immature Leydig cells (Fig. 8C) (Mendis-Handagama \& Ariyaratne 2001). No staining was observed in sections incubated with IgY control (Fig. 8B). Cross-section of the adult testis at low magnification showed PV-1-positive cells within seminiferous tubules at different stages of spermatogenesis, with very few PV-1expressing cells in the interstitium (Fig. 8D). Variable PV-1 staining was evident depending on the stage of 


\section{Adrenal gland}
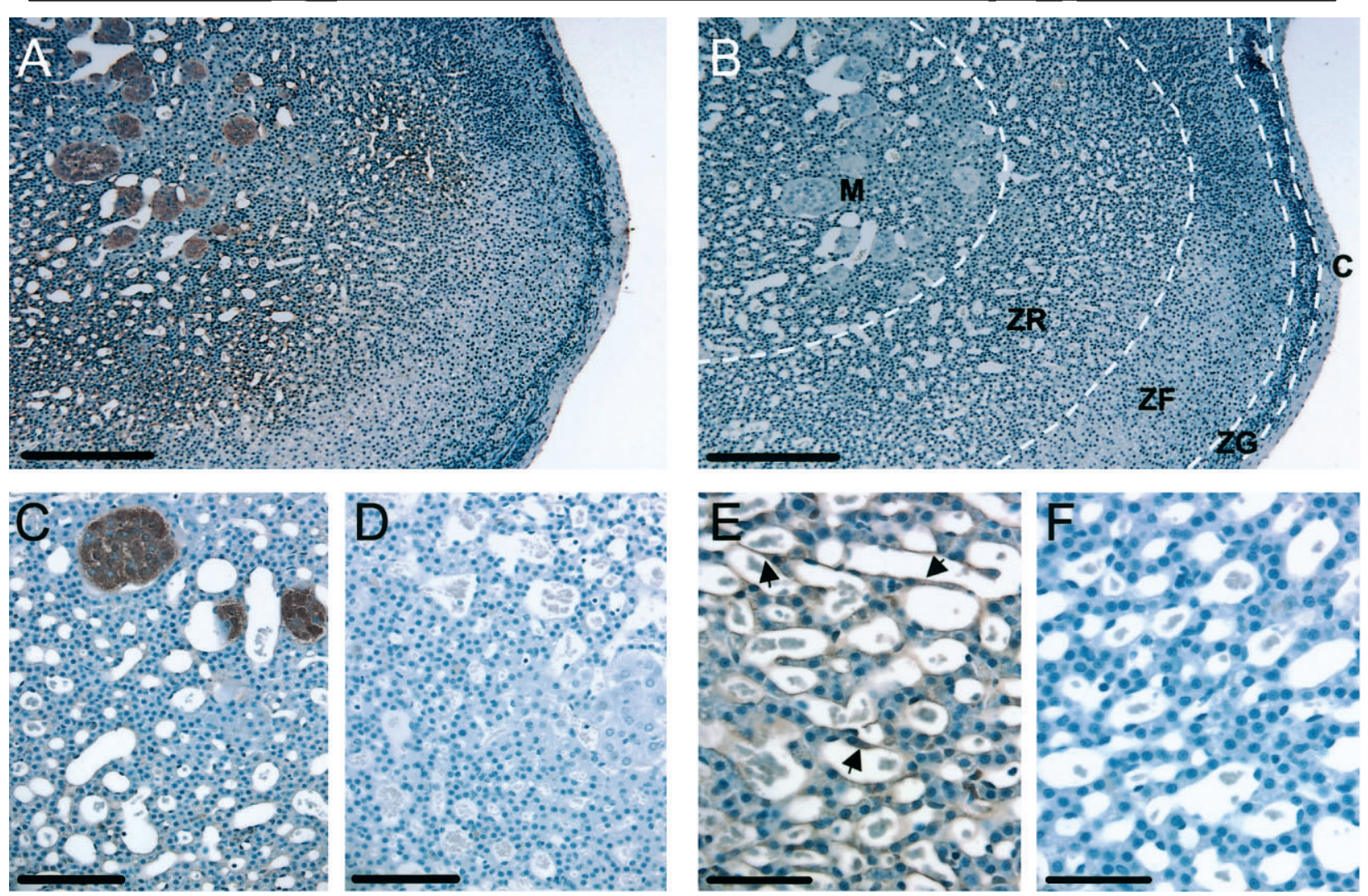

Figure 5 PV-1 distribution in the rat adrenal gland. (A) An $80 \times$ micrograph showing PV-1 staining in discrete anatomical regions of the adrenal gland as designated in the IgY control (B). Bars $=250 \mu \mathrm{m}$. (C) A $200 \times$ micrograph of PV-1 staining in the zona reticularis and the medulla as compared with an IgY control (D). Bars $=100 \mu \mathrm{m}$. (E) A $400 \times$ micrograph that shows PV-1 staining in endothelial cells within the zona reticularis (arrows) as compared with an IgY control (F). Bars $=50 \mu \mathrm{m}$. C, capsule; ZG, zona glomerulosa; ZF, zona fasciculata; $\mathrm{ZR}$, zona reticularis; $M$, medulla.

differentiation within the seminiferous tubule (Hess 1990). For example, Fig. 8F shows PV-1 staining in spermatogonia, spermatocytes and elongated spermatids compared with no staining in IgY controls (Fig. 8E and H). Higher magnification micrographs (Fig. 8G and I) show strong PV-1 staining in Sertoli cells and elongated spermatids and weak staining in round spermatids. PV-1 was undetectable in blood vessels within the interstitium (Fig. 8G).

\section{$P V-1$ is localized within several compartments of the mature ovary}

A low magnification micrograph of the mature ovary shows the distribution of PV-1 (Fig. 9A) in the ovarian stroma, corpus luteum and follicles compared with $\operatorname{IgY}$ control (Fig. 9B). Within the ovarian stroma, both endothelial and non-endothelial cells express PV-1, whereas limited PV-1 staining was seen in cells lining the lumen of a Graafian follicle (Fig. 9C). Over half of the cells within the corpus luteum were positive for PV-1 (Fig. 9D). Figure 9F, G and I show that PV-1 staining is restricted to the thecal layer of ovarian follicles with no staining seen in the IgY control (Fig. 9H).

\section{Discussion}

Using RT-PCR we have shown a single PV-1 gene product that is variably expressed in all the endocrine glands examined. No alternatively spliced transcripts were detected although a truncated form lacking nucleotides 116-252 was previously reported (Stan et al. 1999a). It is noteworthy that the PCR reactions required inclusion of DMSO to prevent production of multiple transcripts likely caused by the high guanine-cytosine (GC) content of PV-1 and secondary structure interruptions of the DNA polymerase (Choi et al. 1999). The weak expression of PV-1 in the pancreas likely reflects its limited cellular 


\section{Pancreas}
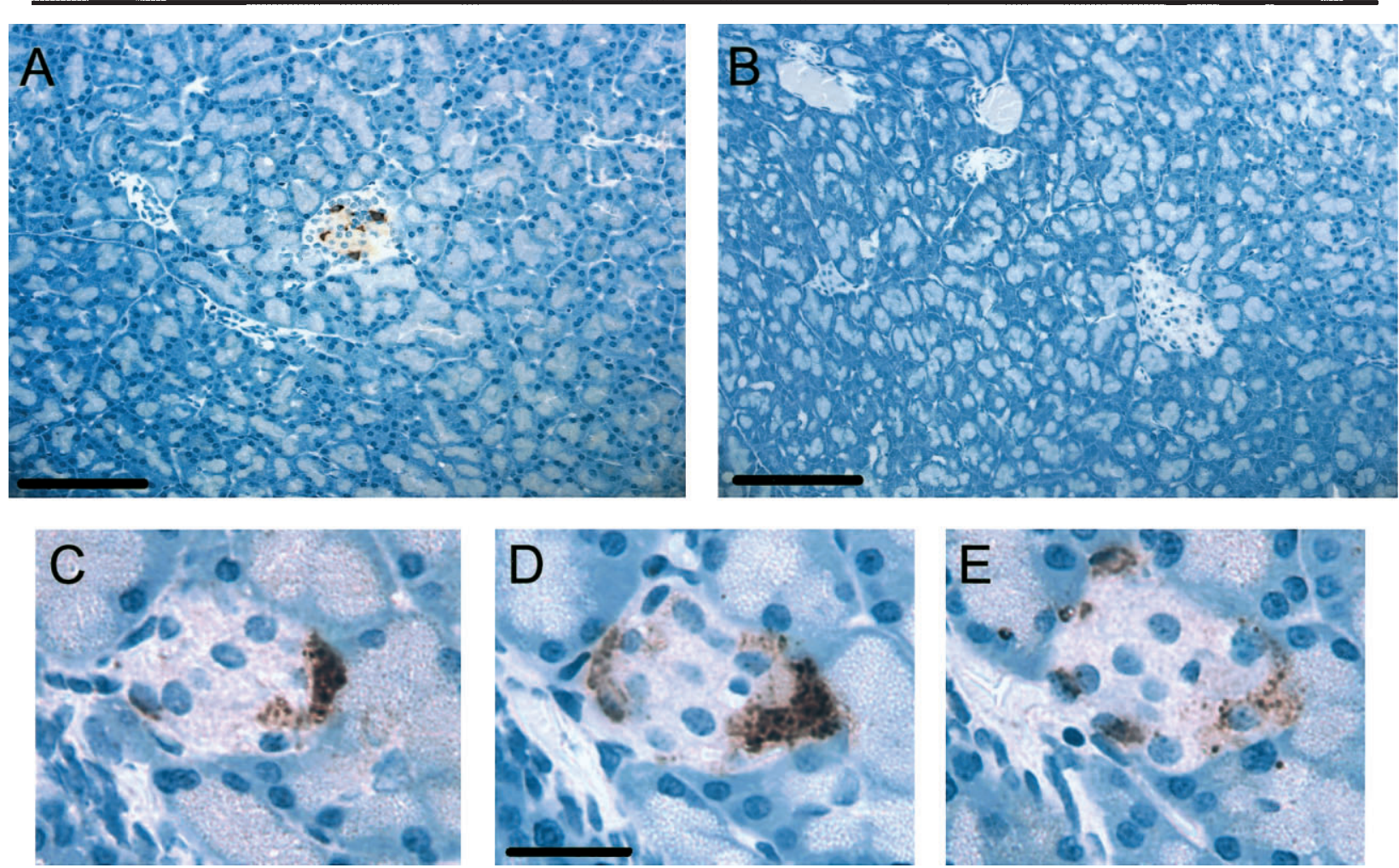

Figure 6 PV-1 distribution in the endocrine pancreas. (A) A $200 \times$ micrograph that shows the exocrine and endocrine pancreas stained for PV-1 compared with an IgY control (B). Bars $=100 \mu \mathrm{m}$. (C-E) Serial sections $(400 \times)$ of a single islet of Langerhans. (C-E) Stained for PV-1 and (D) stained for somatostatin. Bars $=25 \mu \mathrm{m}$.

distribution in the endocrine islets. In a previous report, PV-1 was not detected in the testis using Northern blot (Stan et al. 1999a); however, the use of the more sensitive RT-PCR enables its detection in the present study.

We generated a chicken antibody against a PV-1 peptide that detected a major $65 \mathrm{kDa}$ protein band by Western blotting in membrane fractions from multiple tissues. This is considerably higher than the predicted molecular weight of PV-1, but significant glycosylation (>15\% (Stan et al. 1999a)) and secondary structures might contribute to the observed molecular weight (Holmes et al. 1996). Several weak bands, e.g. $30 \mathrm{kDa}, 60 \mathrm{kDa}$ and $130 \mathrm{kDa}$, were detected at higher protein loads and longer exposure to X-ray film. Whereas the smaller bands may represent proteolytic products, the higher band could be due to aggregation or incompletely dissociated dimers. All of these bands were evident in PV-1-transfected Cos cells, but not in wild-type cells or when the antibody was preabsorbed with the peptide, demonstrating their origin from the PV-1 protein. The difficulty of extracting integral membrane proteins has been well documented (Hooper 1999, Hao et al. 2001, Tate 2001), and likely explains the apparent discrepancy of PV-1 detection between Western blotting and immunohistochemistry.

A novel observation is the strong binding of PV-1 from both rat lung membranes and transfected Cos-1 cells to heparin. This suggests that PV-1 may interact with heparan sulfate proteoglycans located on cell surfaces or in the extracellular matrix. This class of proteoglycans mediate interactions with the cytoskeleton, anchoring it to the extracellular matrix (Jalkanen 1987), as well as binding proteins involved in cell adhesion, migration and growth

Figure 7 (Opposite) Comparison of PV-1 distribution in the neonatal and adult pituitary gland. (A and B) IgY controls (200 $\times$ ) depicting the three lobes of the pituitary gland. PV-1 (C) and GFAP (E) staining in the neonatal pituitary are compared with those of the adult (D) and (F) respectively. Bars $=50 \mu \mathrm{m}$. (G) A $400 \times$ micrograph showing PV-1 staining in endothelial cells (arrows) of the neonatal anterior lobe compared with that in the adult $(\mathrm{H}$; black arrows indicate endocrine cells and red arrows endothelial cells). Bars $=50 \mu \mathrm{m}$. (I) $\mathrm{A} 600 \times$ micrograph of PV-1 staining in the neonatal neural lobe (red arrows indicate nuclear staining; bar $=50 \mu \mathrm{m}$ ) compared with a $400 \times$ micrograph $(\mathrm{J})$ of the adult (bar $=100 \mu \mathrm{m})$. 


\section{Pituitary gland}

\section{Neonate}
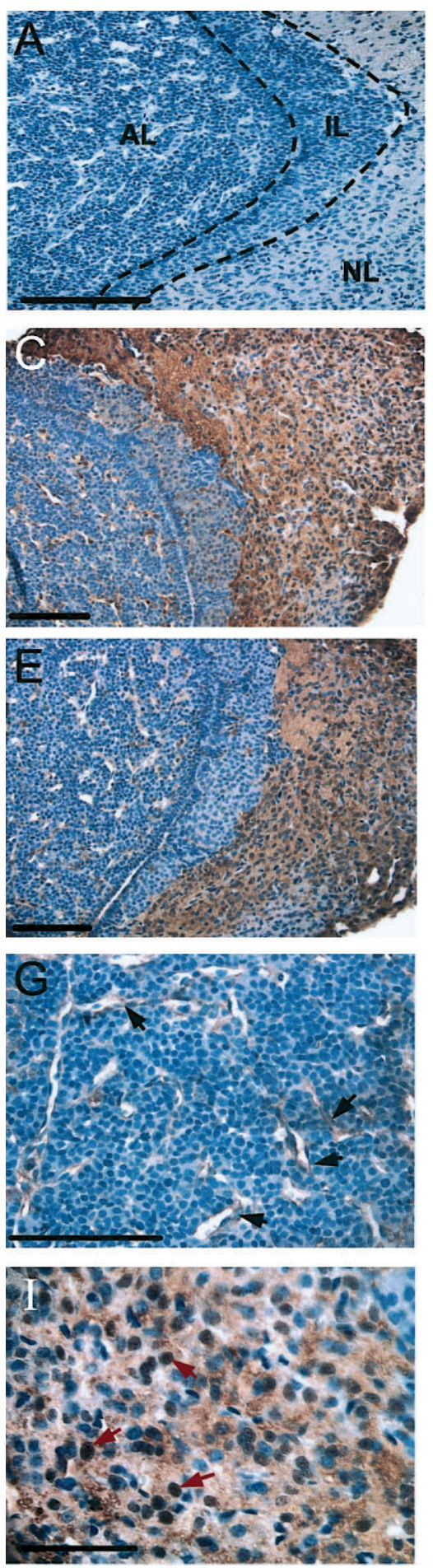

Adult
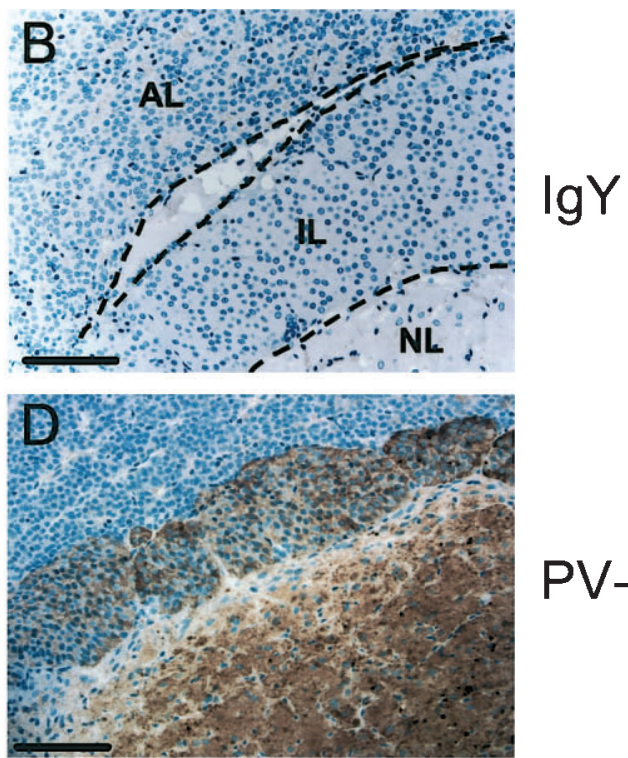

$\mathrm{PV}-1$

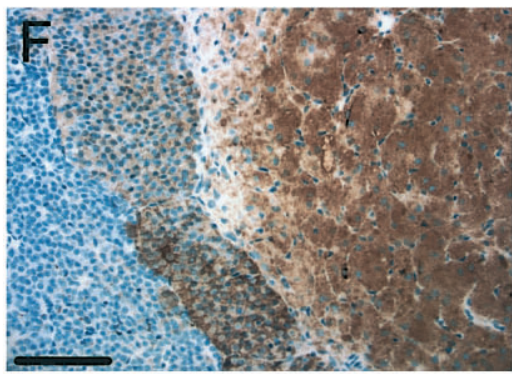

GFAP

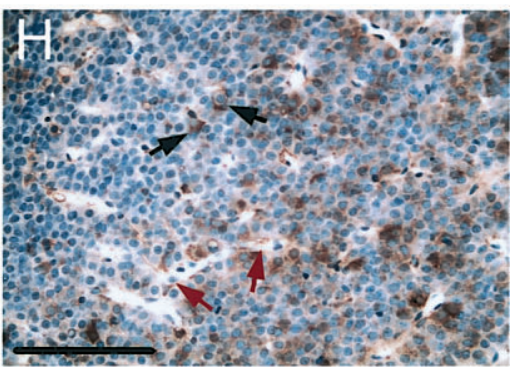

$A L(P V-1)$

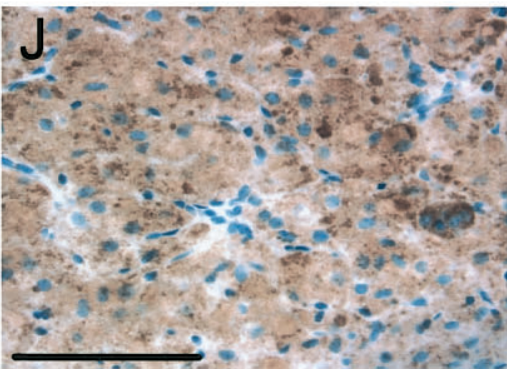

NL (PV-1) 


\section{Testis}

\section{Neonate}
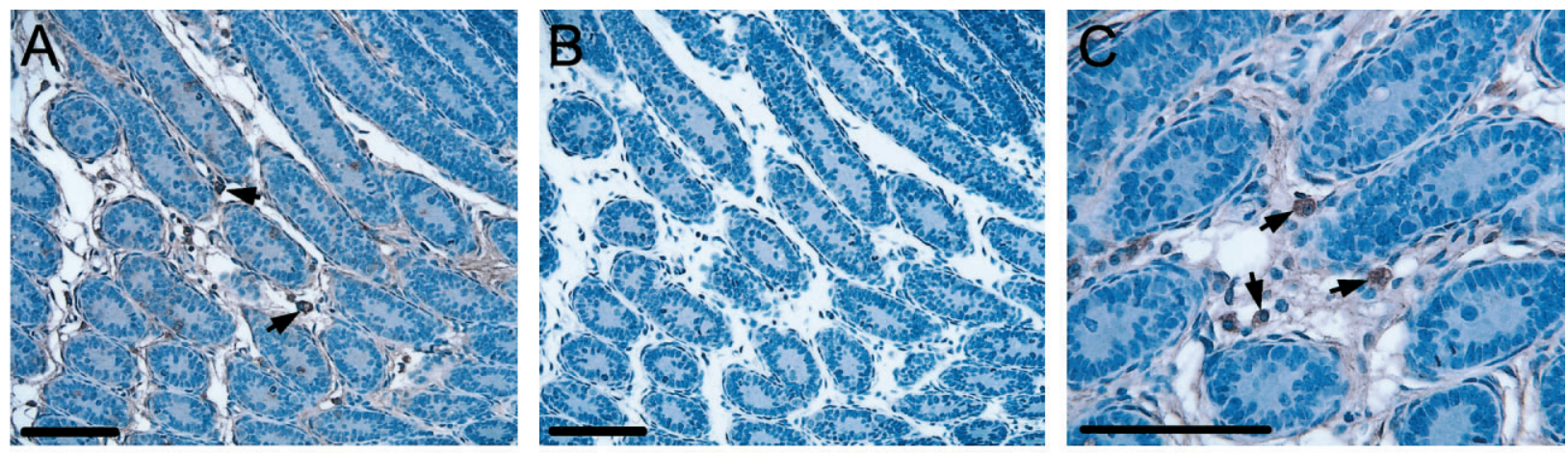

\section{Adult}
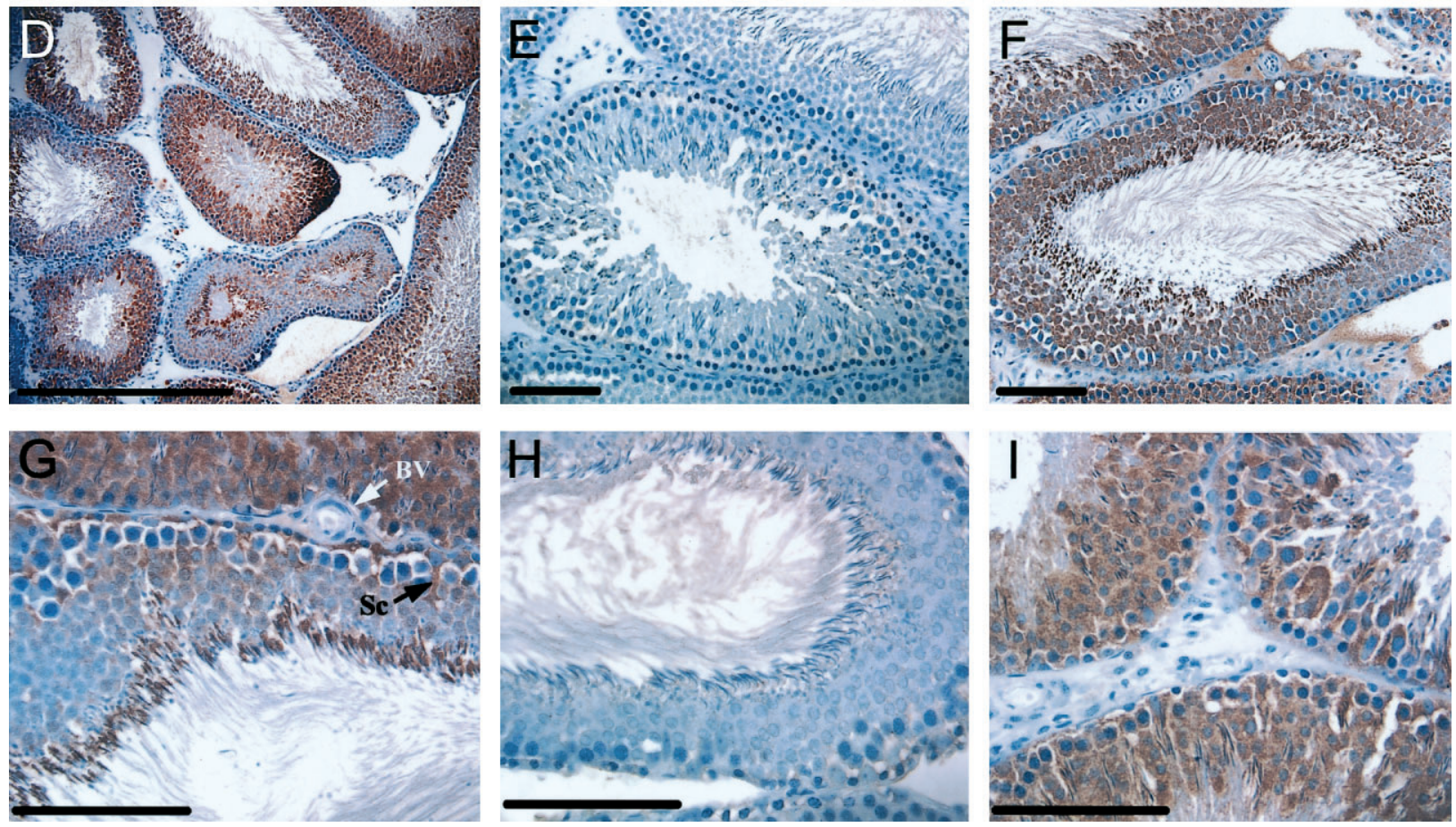

Figure 8 Comparison of PV-1 distribution in the neonatal and adult testis. (A) $(200 \times)$ and (C) $(400 \times)$ show PV- 1 staining in interstitial cells (arrows) of neonatal testis compared with an IgY control (B). Bars $=100 \mu \mathrm{m}$. (D) $(100 \times)$; bar $=500 \mu \mathrm{m},(\mathrm{F})(200 \times)$ and $(\mathrm{G}$ and I) $(400 \times)$ show PV-1 staining in the seminiferous tubules of the adult testis as compared with IgY controls in $(E)(200 \times)$ and $(H)(400 \times)$. Bars $=100 \mu \mathrm{m}$. Sc, Sertoli cell; BV, blood vessel.

(Iozzo 1988, Yurchenco \& Schittny 1990, Tumova et al. 2000). The functional significance of PV-1 binding to heparin remains to be determined, but suggests that it may participate in the organization of the extracellular matrix.

We defined a successful methodology for PV-1 immunohistochemistry after trying several fixatives, optimizing antigen retrieval using microwaves and employing biotinavidin amplification. The specificity of the PV-1 immunostaining in every tissue was validated by the appropriate use of $\operatorname{IgY}$ control antibodies. Moreover, the utility of this technique for detecting antigens was validated by the appropriate cellular localization of well-characterized 


\section{Ovary}
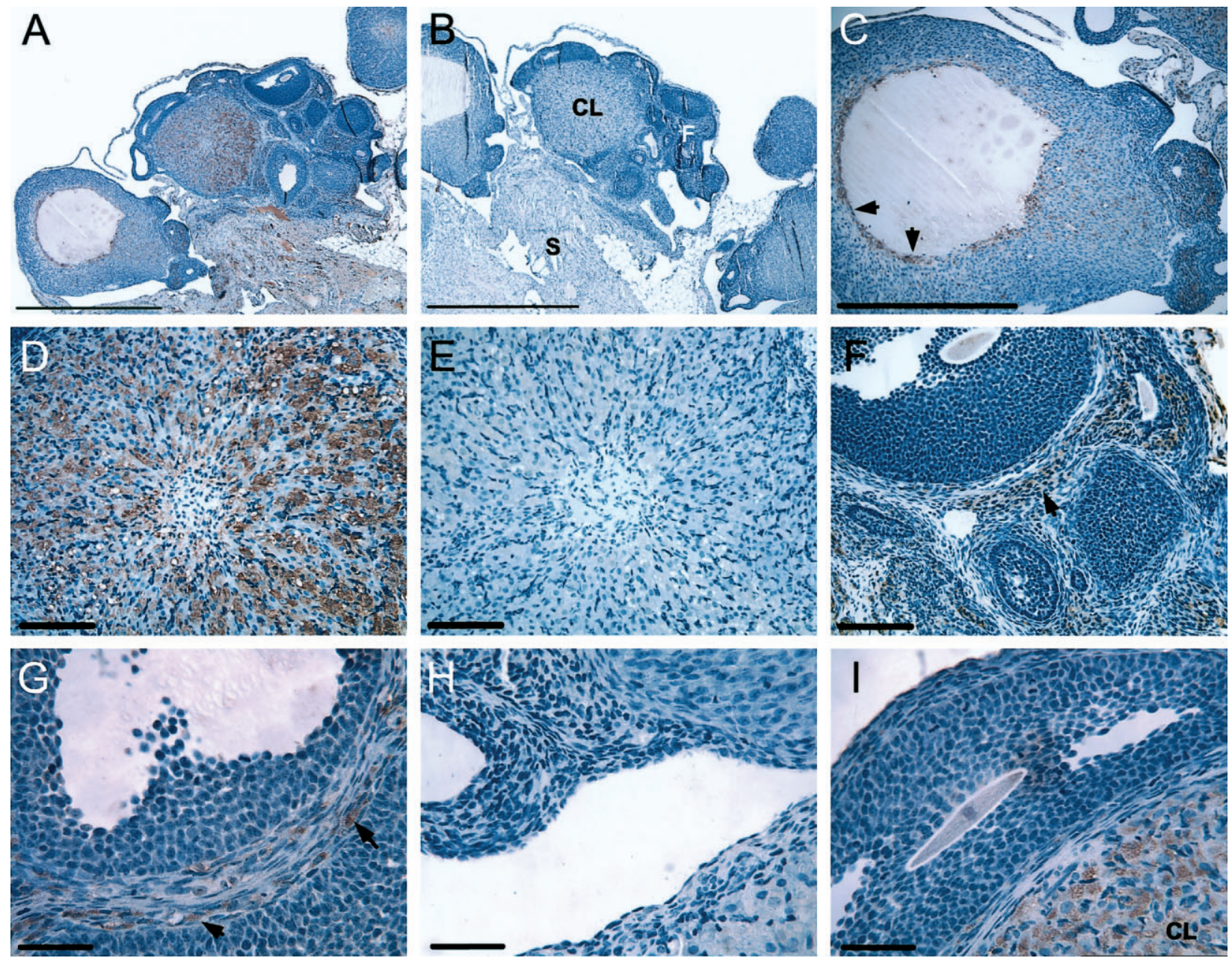

Figure 9 Distribution of PV-1 in the adult ovary. (A) A $40 \times$ micrograph that shows PV-1 or IgY (B) staining in the mature ovary. Bars $=1 \mathrm{~mm}$. (C) A $100 \times$ micrograph that shows PV-1 staining within a Graafian follicle (arrows). Bar $=500 \mu \mathrm{m}$. (D) A $200 \times$ micrograph showing PV-1 staining in cells of a corpus luteum as compared with an IgY control (E). Bars $=100 \mu \mathrm{m}$. (F) $(200 \times)$; bar=100 $\mu \mathrm{m},(\mathrm{G})$ $(400 \times)$ and $(\mathrm{I})(400 \times)$ show PV-1 staining in the thecal layer (arrows) of maturing follicles as compared with an IgY control $(\mathrm{H})$. Bars $=50 \mu \mathrm{m}$. S, stroma; $\mathrm{CL}$, corpus luteum; $\mathrm{F}$, follicle.

antigens such as GFAP and somatostatin (Goldsmith et al. 1975, Salm et al. 1982). We have confirmed a previous report that PV-1 is localized to the fenestrated endothelia of the zona reticularis within the adrenal cortex (Stan et al. 1999b). However, strong PV-1 staining was also seen in the chromaffin cells in the medulla, establishing that its distribution is not limited to endothelial cells. In the pancreas, PV-1 distribution was restricted to a small number of endocrine cells within the islets of Langerhans and was non-detectable in the exocrine pancreas or its endothelial cells. The sparse distribution of PV-1 within the islets resembles that of $\gamma$ - or $\delta$-cells (Baetens et al. 1979, Kaung 1985). Although there was an apparent overlap of PV-1 with somatostatin-positive cells in serial sections, confirmation of their co-localization would require a dual labeling approach.

Developmental differences were observed in the distribution of both PV-1 and GFAP in the pituitary gland. In both the neonate and the adult, PV-1 expression in the NL parallels that of GFAP, a cytoskeletal protein that is prevalent in both pituicytes and astrocytes (Hajos \& Kalman 1989, Shehab et al. 1990). Therefore, it would be of interest to examine whether PV-1 localizes to astrocytes within the brain. A notable absence of PV-1 staining was observed in some NL cells, especially in the marginal cells adjacent to the IL. The expression of PV-1 in the neonatal 
IL was less intense than that of the adult. Whereas there was little GFAP expression in the neonatal IL, it overlaps with that of PV-1 in the adult. Expression of GFAP in the adult IL has been previously reported (Dickerson et al. 1994, Gary et al. 1995). Throughout the anterior lobe of the neonate, both PV-1 and GFAP localized to endothelial cells. On the other hand, PV-1 in the adult AL was clearly seen in some endocrine cells while its expression in endothelial cells was limited to some regions of the AL. Dual immunostaining should identify which hormonesecreting cells also express PV-1.

Perhaps our most striking finding was the dramatic developmental changes in the cellular distribution of PV-1 in the testes. The majority of PV-1-positive cells in the neonatal testis were confined to interstitial cells, likely precursors of Leydig cells, with a limited expression in some gonocytes within the seminiferous tubules (MendisHandagama \& Ariyaratne 2001). In contrast, there was a notable absence of PV-1 in the interstitial cells of the adult testis with a robust expression within the seminiferous tubules. The expression of PV-1 in the various cell types of the seminiferous tubules appears stage dependent and a more detailed examination of the various stages of spermatogenesis will be required to identify the cohorts of spermatogonia/spermatocytes that express PV-1 (Hess 1990). It is clear that spermatids have strong PV-1 expression, but we have not yet determined if mature sperm within the epididymis also express this protein. Unlike the testis, many blood vessels within the ovarian stroma express PV-1 protein along with other stromal cells. PV-1 was detectable in some cells within the thecal layer of developing follicles but was absent from granulosa cells except for a thin layer of cells lining the lumen of Graafian follicles. There was extensive PV-1 expression by many of the luteal cells within the corpus luteum. It will be interesting to determine whether ovarian PV-1 is developmentally or hormonally regulated.

Initially thought to be a specific endothelial cell antigen localized to caveolae and fenestrae, our data demonstrate that PV-1 is expressed in multiple endocrine cell types and in some, but not all, endocrine endothelial cells. Although PV-1 may have a specific function in the caveolae and fenestrae of endothelial cells, it likely has a role beyond these organelles. It is noteworthy that PV-1 staining was also seen in the nuclear compartment of some cells within the neonatal NL (Fig. 7I), suggesting that its localization may not be restricted to the plasma membrane. The use of confocal microscopy should help in resolving the association of PV-1 with various cellular compartments and organelles. The absence of PV-1 expression in the seminiferous tubules of the developing testes, compared with its discrete cellular expression in the adult, suggests a role for PV-1 during spermatogenesis and its potential regulation by hormones. Ongoing studies examine the ontogeny of PV-1 expression throughout the pituitary-gonadal axis in both male and female rats.

\section{Acknowledgements}

We would like to thank Dr Radu Stan for the generous gift of his anti-PV-1 for the initial testing and his suggestions regarding the generation of the PV-1C synthetic peptide. The technical assistance of Tamera Zelenovic is appreciated. This work was supported by NIH grants ES10154, ES09555, and CA80920, NSF grant 9986713 and a grant from the Pardee Foundation.

\section{References}

Baetens D, Malaisse-Lagae F, Perrelet A \& Orci L 1979 Endocrine pancreas: three-dimensional reconstruction shows two types of islets of Langerhans. Science 206 1323-1325.

Bankston PW \& Milici AJ 1983 A survey of the binding of polycationic ferritin in several fenestrated capillary beds: indication of heterogeneity in the luminal glycocalyx of fenestral diaphragms. Microvascular Research 26 36-48.

Bearer EL \& Orci L 1985 Endothelial fenestral diaphragms: a quick-freeze, deep-etch study. Journal of Cell Biology 100 418-428.

Choi JS, Kim JS, Joe CO, Kim S, Ha KS \& Park YM 1999 Improved cycle sequencing of GC-rich DNA template. Experimental and Molecular Medicine 31 20-24.

Clough G 1991 Relationship between microvascular permeability and ultrastructure. Progress in Biophysics and Molecular Biology 55 47-69.

Couet J, Belanger MM, Roussel E \& Drolet MC 2001 Cell biology of caveolae and caveolin. Advances in Drug Delivery Reviews 49 223-235.

Dickerson DS, Huerter BS, Morris SJ \& Chronwall BM 1994 POMC mRNA levels in individual melanotropes and GFAP in glial-like cells in rat pituitary. Peptides 15 247-256.

Esser S, Wolburg K, Wolburg H, Breier G, Kurzchalia T \& Risau W 1998 Vascular endothelial growth factor induces endothelial fenestrations in vitro. Journal of Cell Biology 140 947-959.

Gary KA, Sands SA \& Chronwall BM 1995 Glial-like cells of the rat pituitary intermediate lobe change morphology and shift from vimentin to GFAP expression during development. International Journal of Developmental Neuroscience 13 555-565.

Goldsmith PC, Rose JC, Arimura A \& Ganong WF 1975 Ultrastructural localization of somatostatin in pancreatic islets of the rat. Endocrinology 97 1061-1064.

Gross PM, Blasberg RG, Fenstermacher JD \& Patlak CS 1987 The microcirculation of rat circumventricular organs and pituitary gland. Brain Research Bulletin 18 73-85.

Gumbleton M, Abulrob AG \& Campbell L 2000 Caveolae: an alternative membrane transport compartment. Pharmacological Research 17 1035-1048.

Hajos F \& Kalman M 1989 Distribution of glial fibrillary acidic protein (GFAP)-immunoreactive astrocytes in the rat brain. II. Mesencephalon, rhombencephalon and spinal cord. Experimental Brain Research 78 164-173.

Hao M, Mukherjee S \& Maxfield FR 2001 Cholesterol depletion induces large scale domain segregation in living cell membranes. PNAS 98 13072-13077.

Hess RA 1990 Quantitative and qualitative characteristics of the stages and transitions in the cycle of the rat seminiferous epithelium: light microscopic observations of perfusion-fixed and plastic-embedded testes. Biology of Reproduction 43 525-542.

Holmes EH, Greene TG, Tino WT, Boynton AL, Aldape HC, Misrock SL \& Murphy GP 1996 Analysis of glycosylation of prostate-specific membrane antigen derived from LNCaP cells, prostatic carcinoma tumors, and serum from prostate cancer patients. Prostate 7 (Suppl) 25-29. 
Hooper NM 1999 Detergent-insoluble glycosphingolipid/ cholesterol-rich membrane domains, lipid rafts and caveolae (review). Molecular Membrane Biology 16 145-156.

Iozzo RV 1988 Cell surface heparan sulfate proteoglycan and the neoplastic phenotype. Journal of Cellular Biochemistry 37 61-78.

Irie S \& Tavassoli M 1991 Transendothelial transport of macromolecules: the concept of tissue-blood barriers. Cell Biology Reviews 25 317-333.

Jalkanen M 1987 Biology of cell surface heparan sulfate proteoglycans. Medicine and Biology 65 41-47.

Kaung HC 1985 Glucagon and pancreatic polypeptide immunoreactivities co-exist in a population of rat islet cells. Experientia 41 86-88.

LeCouter J, Kowalski J, Foster J, Hass P, Zhang Z, Dillard-Telm L, Frantz G, Rangell L, DeGuzman L, Keller GA, Peale F, Gurney A, Hillan KJ \& Ferrara N 2001 Identification of an angiogenic mitogen selective for endocrine gland endothelium. Nature $\mathbf{4 1 2}$ $877-884$.

Lombardi T, Montesano R, Furie MB, Silverstein SC \& Orci L 1986 Endothelial diaphragmed fenestrae: in vitro modulation by phorbol myristate acetate. Journal of Cell Biology 102 1965-1970.

Lugo DI \& Pintar JE 1996 Ontogeny of basal and regulated proopiomelanocortin-derived peptide secretion from fetal and neonatal pituitary intermediate lobe cells: melanotrophs exhibit transient glucocorticoid responses during development. Developmental Biology 173 110-118.

Matveev S, Li X, Everson W \& Smart EJ 2001 The role of caveolae and caveolin in vesicle-dependent and vesicle-independent trafficking. Advances in Drug Delivery Reviews 49 237-250.

Mendis-Handagama SM \& Ariyaratne HB 2001 Differentiation of the adult Leydig cell population in the postnatal testis. Biology of Reproduction 65 660-671.

Milici AJ, L'Hernault N \& Palade GE 1985 Surface densities of diaphramged fenestrae and transendothelial channels in different murine capillary beds. Circulation Research 56 709-717.

Milici AJ, Peters KR \& Palade GE 1986 The endothelial pocket. A new structure in fenestrated endothelia. Cell and Tissue Research $\mathbf{2 4 4}$ 493-499.
Roberts WG \& Palade GE 1995 Increased microvascular permeability and endothelial fenestration induced by vascular endothelial growth factor. Journal of Cell Science 108 2369-2379.

Salm AK, Hatton GI \& Nilaver G 1982 Immunoreactive glial fibrillary acidic protein in pituicytes of the rat neurohypophysis. Brain Research 236 471-476.

Shehab SA, Cronly-Dillon JR, Nona SN \& Stafford CA 1990 Preferential histochemical staining of protoplasmic and fibrous astrocytes in rat CNS with GFAP antibodies using different fixatives. Brain Research 518 347-352.

Simionescu N, Lupu F \& Simionescu M 1983 Rings of membrane sterols surround the openings of vesicles and fenestrae, in capillary endothelium. Journal of Cell Biology 97 1592-1600.

Stan RV, Ghitescu L, Jacobson BS \& Palade GE 1999a Isolation, cloning, and localization of rat PV-1, a novel endothelial caveolar protein. Journal of Cell Biology 145 1189-1198.

Stan RV, Kubitza M \& Palade GE 1999 bV PV-1 is a component of the fenestral and stomatal diaphragms in fenestrated endothelia. PNAS $9613203-13207$.

Stan RV, Arden KC \& Palade GE 2001 cDNA and protein sequence, genomic organization, and analysis of cis regulatory elements of mouse and human PLVAP genes. Genomics 72 304-313.

Takakura Y, Mahato RI \& Hashida M 1998 Extravasation of macromolecules. Advances in Drug Delivery Reviews 34 93-108.

Tate CG 2001 Overexpression of mammalian integral membrane proteins for structural studies. FEBS Letters 504 94-98.

Tumova S, Woods A \& Couchman JR 2000 Heparan sulfate proteoglycans on the cell surface: versatile coordinators of cellular functions. International Journal of Biochemistry and Cell Biology 32 269-288.

Yurchenco PD \& Schittny JC 1990 Molecular architecture of basement membranes. FASEB Journal 4 1577-1590.

Received in final form 23 July 2002

Accepted 2 August 2002 